\title{
Using "Closed Group" Facebook to teach writing for the tenth graders of SMAN 1 Jiwan
}

\author{
Lilis Suganda \\ Department of English Teaching, Universitas PGRI Madiun, Indonesia
}

\begin{tabular}{l}
\hline Article Info \\
\hline Article history: \\
Received January 12, 2018 \\
Revised March 20, 2018 \\
Accepted Mei 29, 2018
\end{tabular}

\section{Keywords:}

Facebook

Facebook Closed Group

Writing

Descriptive Text

\begin{abstract}
This research aims at improving the writing learning process of the tenth graders of SMA Negeri 1 Jiwan through closed group Facebook. This research used descriptive qualitative research and data collected using methodological triangulation. Then, to collect the data, researcher needs a technique that is called technique of collecting data. There were observation, interview and documentation.Based on the result of this research, Closed Group Facebook is more interesting than write on paper, helps the students to active in teaching writing, makes easier to share problem in their writing, can increase the students' interest to learn writing, makes the students easily understand their mistake in writing by giving friend's feedback in the comment, makes the students enjoy in learning writing.Meanwhile, the disadvantages are first, Closed Group Facebook only can be accessed if there is quota internet or access wi-fi. The second, students' activity can not be controlled by the teacher when they are opening Facebook or when they operate their gadget. It can be concluded that using closed group Facebook can improve students' writing skill. The last, the researcher also gives the suggestion for the teacher, students, school, and future researcher that they should do better research.
\end{abstract}

Copyright $@ 2018$ Department of English Teaching. All rights reserved.

Corresponding Author:

Lilis Suganda,

Department of English Teaching,

Universitas PGRI Madiun,

Jalan Setiabudi No.85 Madiun, Eas Java, Indonesia.

Email: lilis_sanda@yahoo.com

\section{INTRODUCTION}

Writing is one of the important skills that should be mastered by the students. They need to express their feeling and ideas in a good way creatively, so the reader can understand their writing. The students are expected to be able to analyse the social function, structure, and language features of descriptive text. Good writing skills allow someone to communicate a message with clarity and ease to understand. In Senior High School, teaching writing in English is also a compulsory subject to be taught. Good writing skills are important for effective communication for SMA students, communication is not only speaking to transfer idea but students can type their idea in teaching writing process. Teacher must provide various learning activities that can support the learning of specific writing skills. Based on the Curriculum 2013, the students in senior high level have to be able write some kinds of text in order to achieve the learning goals formulated by Goverment. One those text is descriptive text. descriptive text is a text which describe and says what a person or thing is like. Its purpose is to describe and reveal a particular person, place, or thing.

While the students still face problems in writing English text, students feel difficult to transfer their idea into text. The students' problems in writing English text are the lack of vocabularies, incorrect punctuations 
and spelling, etc. They do not know how to make a good sentence and to organize writing. According to Karani (2008: 11), there are four problems encountered by the students when they are ordered to write a text. They are problems in content, organizing, vocabulary, and grammar. First is content, the students can't produce an effective text because they can't construct the main idea and supporting detail into a paragraph. Second is organizing, the students cannot organize paragraph into a good text. Third is vocabulary. Sometimes, the students lack of vocabulary for constructing a good paragraph, so the students cannot convey their ideas and opinions smoothly. Fourth is grammar. A good text describes a sentence structure correctly and the paragraph has a good order of the word in sentence sequence. Briefly, their problems are on the writing procedures, and they usually lack of vocabulary and grammar mastery to start writing English text.

In this case, the writer wants to apply closed group Facebook as a medium of instruction in teaching writing to be more effective. Using Facebook to support learning is in accordance with the social constructivism paradigm, which emphasizes social interaction and learning from others in the group. Facebook closed group is chosen because it gives more privacy to the members. Only group members can read and comment on the posts. Anything posted in the closed group does not appear in the members' logs as do their other Facebook activities. It is visible only to other group members (Meishar-Tal, Kurtz, andPieterse, 2012). Another convenience is that a Facebook user can join and be approved as a member without having to be friends with the creator, so teacher and students do not have to share their profile and statuses with each other.

Teacher can take some benefits from students' activity in writing descriptive text using closed group Facebook. They can improve the students writing ability by motivating them to write in teaching learning activity. This media is applied in the class, teacher ask student to write a descriptive text and post it into closed group Facebook. After that, other students will give comment about their friends' writing that have posted in group. The last, teacher give feedback to them in closed group Facebook.

Some previous researches related to this research. First, a research was done by Rodliyah R.S, (2016) shows that using close group Facebook can improve students' writing skill, she found that students actively and quickly participated in both asking and answering the teacher's questions. In addition, the students also shared their new knowledge even after the classes have ended and grades were assigned. Second, Cahyono B.Y, (2009) states that taught by using closed group Facebook toward teaching writing shows that students' writing skill can improve by using Facebook. By applying this, all of the students will know each other in this closed group Facebook. The group will support each member and provide opportunities to practice and discuss the content of the material task or given. Therefore, based on the background above the researcher wants to solve the problem of students in teaching writing. In this research, the researcher wants describe the using a Facebook closed group EFL Student's writing for the tenth graders of senior high school and to understand about advantages and disadvantages. The researcher would like to do a research about using "closed group" Facebook to teach writing for the tenth graders of SMA Negeri 1 Jiwan.

\section{METHOD}

This research used qualitative research. The researcher used the phenomena that was happened as the data to be analysed. Khotari (2004:3) define that "Qualitative research, on the other hand, is concerned with 
qualitative phenomenon, i.e, phenomena relating to or involving quality or kind. For instance, when we are interested in investigating the reasons for human behaviour (i.e., why people think or do certain things)". The participant of the research were all members involved in the English teaching learning processes in grade X. They were the English teacher of class X and the students of class XC at SMA Negeri 1 Jiwan.

Then, to collect the data, researcher needs a technique that is called technique of collecting data. There were observation, interview and documentation. In this research, the analysis of document focused on the chosen documents, include data of the students: list of scores, teacher's lesson plan, syllabus and visual. The aim is to contribute the data observation and data interview. In the qualitative research, data can be used validity technique called triangulation. Validity was the most important idea to consider when preparing or selecting an instrument for use. The valid research could be as the collection or interpretation of data that show the result of research is accurate. In this research, the researcher usedMethodological Triangulation to measure the validity of the data.

In this research, there are some steps to use closed group Facebook to improve a writing learning process by several activities. Those are:

a. The teacher gives a material in Facebook that have explained orally to remind the students and they can re-read the materials.

b. The teacher asks student to uploads picture, and the students must make a descriptive text about the picture.

c. The teacher asks students to make a descriptive text and post it in Facebook and the other students must give feedback to them.

d. The students can utilize the chatting room in Facebook to ask the teacher about the problems related to the material in the classroom.

This research was delivered the teaching and learning process for the tenth graders of SMA Negeri 1 Jiwan, So, the researcher used some research procedure, they are preparing, collecting data, analysing data, reporting.

\section{RESULTS AND DISCUSSION}

The result of data which are got from observation, interview, and documentation are used to answer the research problem statements such as the implementation, the advantages and the disadvantages of using Facebook closed group to teach writing for the tenth graders of SMA Negeri 1 Jiwan. For answer of the research problem statements can be describe as follows:

\section{The use of a Facebook closed Group EFL student's writing for the tenth graders of SMA Negeri 1} Jiwan

There are three main activities that are done by the teacher in using of a Facebook closed Group EFL student's writing for the tenth graders of SMA Negeri 1 Jiwan. There are pre-activity, whilst activity and post activity.

a. Pre-activity

In the pre-activity, the teacher gives some kind of opening before go to the whilst activity, the simple one like greeting, then the class begins by perform pray. After that, the teacher checks the attendance list and reviewing the material. 
b. Whilst activity

The teacher asks the students about kinds of text to stimulate the student and the students give responses and answer teacher's question. Teacher tells the students about descriptive text and generic structure of descriptive text". After that, teacher gives chances to the students to ask questions. Then, the teacher gives example in making a good sentence by using simple present tense to write descriptive text. the teacher reminds to the students to be careful in spelling and punctuating. The teacher explained and practiced the steps about descriptive text by using closed group Facebook. The teacher gives questions to the students if they have difficulties After that, the teacher asks the class to make a descriptive text about favourite artist by using Closed Group Facebook. After they have finished the teacher give feedback to their posting in the closed group Facebook.

c. Post activity

The last step of teaching learning process in the class is closing. The first activity in closing was that the teacher and students discussed together about student' problem and difficulty in understanding the materials. After that, teacher gives the conclusion of material. Then the teacher closes the lesson by giving farewell greeting. From this observation, the researcher also gets some other data about teaching learning process and the real class situation. When the students ask, the teacher give response clearly. Teacher could maintain the class situation and always control the students when they do their task. In teaching learning process, the students pay attention to the teacher and actively participate in the learning process. They also obey the rules and follow teaching learning process enthusiastically.

2. The advantages and disadvantages using a Facebook closed group for the tenth graders of SMA Negeri 1 Jiwan

There are some advantages and disadvantages using a Facebook closed group for the tenth graders of SMA Negeri 1 Jiwan.

a. The Advantages of Using Closed Group Facebook to Teach Writing for the Tenth Graders of SMA Negeri 1 Jiwan

1. Closed Group Facebook is more interesting than write on paper.

2. Using Closed Group Facebook helps the students to active in teaching writing.

3. Using Closed Group Facebook makes easier to share problem in their writing.

4. Closed Group Facebook can increase the students' interest to learn writing.

5. Closed Group Facebook makes the students easily understand their mistake in writing by giving friend's feedback in the comment.

6. Closed Group Facebook makes the students enjoy in learning writing.

b. The Disadvantages of Using Closed Group Facebook to Teach Writing for the Tenth Graders of SMA Negeri 1 Jiwan.

1. Closed Group Facebook only can be accessed if there is quota internet or access wi-fi.

2. Using Closed Group Facebook, teacher can't control students' activity when they opened the gadget because student might be open other application or chatting with their friends, update status in Facebook. 
In this part, the researcher concludes the discussion about the result of research which is done to the tenth graders of SMA Negeri 1 Jiwan in the schooling year of 2016/2017. Based on the result of this research, it can be concluded that there are some steps in teaching writing by using Facebook closed group, in this activity consists of three activities they are pre-activities, whilst activities, and post- activities. In the preactivity, the teacher gives some kind of opening before go to the whilst activity, the simple one like greeting, then the class begins by perform pray. After that, the teacher checks the attendance list and reviewing the material. Second is whilst activities, in this activity the teacher asks the students about kinds of text to stimulate the student and the students give responses and answer teacher's question. Teacher tells the students about descriptive text and generic structure of descriptive text. After that, teacher gives chances to the students to ask questions. Then, the teacher gives example in making a good sentence by using simple present tense to write descriptive text. the teacher reminds to the students to be careful in spelling and punctuating. The teacher explains and practices the steps about descriptive text by using closed group Facebook the teacher gives questions to the students if they have difficulties After that, the teacher asks the class to make a descriptive text about favourite artist by using Closed Group Facebook. After they have finished the teacher give feedback to their posting in the closed group Facebook. The last activity is postactivities. In this activity, the teacher and students discuss together about students' problem and difficulty in understanding the materials. After that, teacher gives the conclusion of material. Finally, the teacher closes the lesson by giving farewell greeting.

\section{CONCLUSION}

Based on the implementation of teaching writing through a Facebook closed group for the tenth graders of SMA N 1 Jiwan Madiun has three steps included pre-activity, whilst-activity, and post- activity. Some advantages of teaching writing through a Facebook closed group for the tenth graders of SMA N 1 Jiwan Madiun in the schooling year 2016/ 2017 are first, using closed group Facebook more interesting than writing on paper, then helps to active in teaching writing, it makes students easier to share problem in their writing, using Closed Group Facebook helps the students to enjoy writing and they can see their friend's work each other. It also makes them to correct and edit their writing if there are mistakes so the condition of the class more fun. Second, students can improve their score in teaching writing because they remind their mistake in writing by the comment and how to correct it. Most of students feel easy to write descriptive text in closed group Facebook and they can share about their problem in writing directly. The last, peer feedback in closed group Facebook is useful because their work can get feedback from their friends by comments. It means that most of students can interact each other, they must comment and read their friend's work to look for mistakes so students don't depend by the teacher. Third, the strategy trains the students' concentration. Fourth, the students enjoy in learning reading. Meanwhile, the disadvantages are first, Closed Group Facebook only can be accessed if there is quota internet or access wi-fi. The second, students' activity can not be controlled by the teacher when they are opening Facebook or when they operate their gadget.

\section{REFERENCES}

Azar. B. S. (1999). Understanding and Using English Grammar. New York: Pearson Education. 
Berg, L. B. (2001). Qualitative Research Methods for Social Sciences. United Stated of America: A Person Education Company.

Bogdan, R. C. \& Sari, K. (1982). Qualitative Research for Education: An Introduction tu Theory and Methods. United State of America: Person Education Inc.

Brown, H. D. (2001). Principles of Language Learning and Teaching 4th Edition. New York: Addison Wesley Longman Inc.

Brown, H. D. (2007). Principles of Language Learning and Teaching. (5th Ed.). New York: Longman.

Cahyono, B.Y. (2011). Techniques and strategies to Enhance English Language Learning. Malang: State University of Malang Press.

Cresswell, John W. (2003). Research Design Qualitative, Quantitative, and Mixed Methods Approaches Second Edition. California: Sage Publication Inc.

Gardner, J. C. (2010). Facebook's Potential in the Classroom. Retrieved from: http://www.jclarkgardner.com/uploads/5/4/1/4/5414483/jclark_gardner_faceb ook_classroom. Pdf on July 15 th 2017.

Harmer, J. (2004). How to Teach Writing. Essex: Pearson Education Limited.

Karani, E. (2008). Writing Area of Problems Writing in Recount Text. Jurnal Pendidikan Inovatif, jilid 4 no. 1, september 2008, p. 11.

Khotari, R. C. 2004. Research Methodology. New Delhi: New Age International.

Langan, J. 2005. College writing skills (5th ed.). Boston, MA: McGraw-Hill.Mc. McDonough. 2004. Research methods for English language teachers. London: a Member of the Hodder Headline Group.

Maykut, P., \& Richard, M. 2005. Beginning Qualitative Research a Philosophic and Practical Guide. Francis e-Library: The Falmer Press.

Meishar-Tal, H., Kurtz, G., \&Pieterse, E. (2012). Facebook groups as LMS: Acase study. The International Review of Research in Open and Distance Learning, 13(4), 33-48.

Oshima, A. \& Hogue, A. 1996. Introduction to Academic Writing (Second Edition). Addison Wesley Longman.

Richards, J. C., \& Renandya, W. A. 2002. Methodology in Language Teaching. An Anthology of Current Practice. New York: Cambridge University Press.

Rodliyah R.S. (2016). Using a Facebook Closed Group to Improve EFL Students' Writing. TEFLIN Journal, Volume 27, Number 1.

Sugiyono.2006. Metode Penelitian Manajemen. Bandung: Alfabeta.

Terantino, J. \& Karen, G. 2011. Using Facebook in the Language Classroom as Part of the Net Generation Curriculum. $\quad$ Retrieved from http://www.actfl.org/sites/default/files/pdfs/TLEsamples/TLE_Nov11_Article .pdf on July 6th 2017.

Wahyuni, S. 2012. Qualitative Research method. Jakarta: SalembaEmpat.

Westminster, H. 2013. Facebook Guide for Educators. London: The Education Foundation.

Yunus, M. \& Salehi, Hadi. The Effectiveness of Facebook Groups on Teaching and Improving Writing: Students' Perceptions.

Retrieved

from http://www.naun.org/multimedia/NAUN/educationinformation/17-538.pdf on July 6th 2017. 